\title{
The HIV protease inhibitor saquinavir impairs lipid metabolism and glucose transport in cultured adipocytes
}

\author{
S Ranganathan and P A Kern \\ Department of Medicine, Division of Endocrinology, University of Arkansas for Medical Sciences, and the Central Arkansas Veterans Healthcare System, \\ Little Rock, Arkansas 72205, USA \\ (Requests for offprints should be addressed to P A Kern, Central Arkansas Veterans Healthcare System, 598/151 LR, 4300 West 7th Street, Little Rock, \\ Arkansas 72205, USA; Email: KernPhilipA@uams.edu)
}

\begin{abstract}
Treatment of HIV infection using protease inhibitors is frequently associated with lipodystrophy and impaired lipid and glucose metabolism. We examined the effect of saquinavir, one of the protease inhibitors, on lipid metabolism and glucose transport in cultured adipocytes. Saquinavir inhibited lipoprotein lipase (LPL) activity in 3T3-F442A and 3T3-L1 adipocytes. The inhibition of LPL was $81 \%$ at a concentration of $20 \mu \mathrm{g} / \mathrm{ml}$. Another closely related drug, indinavir, had a small inhibitory effect. Saquinavir also inhibited the biosynthesis of lipids from $\left[{ }^{14} \mathrm{C}\right]$-acetate. Saquinavir increased the lipolysis.
\end{abstract}

Saquinavir had no significant effect on the cellular protein synthesis or protein content. Saquinavir increased the basal glucose transport threefold and decreased insulinstimulated glucose transport by $35 \%$. These studies suggest that some HIV protease inhibitors have direct effects on lipid and glucose metabolism. This inhibition of lipogenesis and glucose transport may explain some of the lipodystrophy, dyslipidemia and disturbed glucose metabolism with the clinical use of these drugs.

Journal of Endocrinology (2002) 172, 155-162

\section{Introduction}

Protease inhibitors are a new class of drugs used for the treatment of human immunodeficiency virus (HIV) infection. These drugs block the replication cycle of HIV by inhibiting the aspartic protease, which is critical in the processing of the products of the gag-pol gene into functional protein of HIV. Gag-pol protein releases the aspartic protease that cleaves the gag-pol protein allowing the virus particle to mature (Kohl et al. 1988). Inhibition of the protease enzyme prevents the maturation of the viral particle and retards the infection. The protease inhibitors are peptide-like substrate analogues that bind to the active site resulting in the inhibition of the enzyme activity (Navia et al. 1988). Clinical studies have shown that these drugs reduce the viral load significantly and improve the CD4+ counts (Schapiro et al. 1996).

Although the drugs are generally well tolerated, several studies have reported that treatment of patients with protease inhibitors causes peripheral lipodystrophy, resulting in loss of fat in all regions except the abdomen, hyperlipidemia and insulin resistance (Carr et al. 1998, 1999). The treatment of HIV with protease inhibitors resulted in an atherogenic hyperlipidemia, with elevated total cholesterol, low density lipoprotein cholesterol and triglycerides (Echevarria \& Hardin 1999, Periard et al. 1999). Purnell et al. (2000) have reported that administration of ritonovir to healthy subjects resulted in hypertriglyceridemia but post-heparin plasma lipoprotein lipase (LPL) remained unchanged. Insulin resistance develops in many patients treated with HIV proteases, and extreme hyperglycemia has been reported with the protease inhibitor nelfinavir (Visnegarwala et al. 1997). These studies suggest that the protease inhibitors may have direct effects on the lipid and glucose metabolism in the fat and muscle tissue.

Previous in vitro studies demonstrated an inhibition of preadipocyte to adipocyte differentiation by protease inhibitors using both human and 3T3-L1 preadipocytes (Wentworth et al. 1999, Zhang et al. 1999). To further examine the effect of HIV protease inhibitors on lipid metabolism, we studied the effects of two such drugs, saquinavir and indinavir, on LPL in vitro in 3T3-F442A adipocyte cultures. LPL-mediated triglyceride hydrolysis is one of the important factors in adipocyte lipid accumulation in humans and rats (Hollenberg 1966, Wilson et al. 1973). The effects of these drugs on lipid accumulation and glucose transport were also investigated. The results showed that saquinavir inhibited LPL activity, lipid synthesis and insulin-stimulated glucose transport. 


\section{Materials and Methods}

\section{Materials}

3T3-F442A and 3T3-L1 cells were obtained from Dr Howard Green (Massachusetts Institute of Technology, Cambridge, MA, USA). Media and other tissue culture supplies were from Gibco-BRL (Grand Island, NY, USA). Human recombinant insulin (Novolin) was obtained from Nordisk Pharmaceuticals (Princeton, NJ, USA). [U- $\left.{ }^{14} \mathrm{C}\right]$-Glucose, 2-deoxy- $\left[{ }^{3} \mathrm{H}\right]$-glucose, $\left[{ }^{35} \mathrm{~S}\right]-$ methionine and $\left[{ }^{3} \mathrm{H}\right]$-triolein were from New England Nuclear (Boston, MA, USA). Bovine serum albumin, triolein, lecithin, 2-deoxyglucose and peroxidaseconjugated anti-rabbit chicken $\operatorname{IgG}$ were purchased from Sigma Chemical Co. (St Louis, MO, USA). Saquinavir and indinavir were dissolved in $25 \%$ ethanol, filtersterilized and used for the experiments described. Polyclonal antibodies against bovine LPL raised in rabbit were a generous gift from Dr Ira Goldberg (Columbia University, New York, NY, USA).

\section{Cell culture}

3T3-F442A cells were maintained in $75 \mathrm{~cm}^{2}$ flasks in low glucose Dulbecco's modified Eagle's Medium (DMEM) supplemented with $10 \%$ calf serum and a mixture of penicillin and streptomycin. For experiments, they were subcultured in 12-well dishes. Confluent cultures were allowed to differentiate by adding DMEM containing 10\% fetal bovine serum and $100 \mathrm{nM}$ insulin. The cells differentiated well in 3-5 days after switching to the differentiation medium. 3T3-L1 cells were differentiated using isobutyldimethylxanthine (IBMX), dexamethasone and insulin as described previously (Clancy \& Czech 1990). In the experiments involving the treatment of the cells with saquinavir during differentiation, the drug was added along with insulin in the case of 3T3-F442A cells or after the $48 \mathrm{~h}$ treatment with differentiation cocktail in the case of 3T3-L1 cells.

3T3-F442A cells were used for studying the effect of these drugs on LPL and lipid metabolism. Since high concentration of insulin was used to differentiate and maintain 3T3-F442A adipocytes, the basal glucose transport was high and not stimulated further by insulin. Hence, for studies on insulin action and glucose transport we used 3T3-L1 adipocytes.

\section{Glucose transport}

After differentiation, 3T3-L1 adipocytes were cultured without insulin for 6-8 days to study insulin-stimulated glucose transport. Before the glucose transport assay, the cells were incubated with $1 \mathrm{ml}$ serum-free DMEM for $4 \mathrm{~h}$. The cells were then washed twice with Krebs-Ringer phosphate buffer and incubated with or without $10 \mathrm{nM}$ insulin in the same buffer for $30 \mathrm{~min} .2$-Deoxy- $\left[{ }^{3} \mathrm{H}\right]-$ glucose was added to give a final concentration of $0 \cdot 1 \mathrm{mM}$ $(1 \mu \mathrm{Ci} / 100 \mathrm{nmol})$ and incubated for $10 \mathrm{~min}$. The medium was aspirated and the cells were washed three times, and dissolved in $0.5 \mathrm{ml} 0.2 \mathrm{M} \mathrm{NaOH}$. Radioactivity in this lysate was determined by scintillation counting. Protein content in the lysate was determined by BioRad reagent (Richmond, CA, USA). Non-carrier-mediated glucose transport was determined in the presence of $10 \mu \mathrm{M}$ cytochalasin (Clancy \& Czech 1990).

\section{LPL assay}

LPL was measured in the medium after release with heparin, as described previously. The culture medium was removed from the dishes and $1 \mathrm{ml}$ fresh medium containing heparin $(10 \mathrm{U} / \mathrm{ml})$ was added and incubated for $60 \mathrm{~min}$ at room temperature. It was found that more than $90 \%$ of the total extractable LPL activity in these cells was released by heparin under these conditions. LPL catalytic activity was measured using an emulsified $\left[{ }^{3} \mathrm{H}\right]$-triolein substrate as described previously (Nilsson-Ehle \& Schotz 1976). After incubation of $100 \mu \mathrm{l}$ sample with $100 \mu \mathrm{l}$ substrate for $60 \mathrm{~min}$, liberated $\left[{ }^{3} \mathrm{H}\right]$-fatty acids were separated from the reaction mixture using the method of Belfrage \& Vaughn (1969). The LPL activity is expressed as nmol fatty acids released in $60 \mathrm{~min} / \mathrm{mg}$ cell protein.

\section{Incorporation of $\left[{ }^{14} \mathrm{C}\right]$-acetate into lipids}

To study the biosynthesis of total lipids from acetate, the cells were incubated with $\left[{ }^{14} \mathrm{C}\right]$-acetate for $1 \mathrm{~h}$ at $37^{\circ} \mathrm{C}$ in phosphate-buffered saline and washed five times with the same buffer. Total lipids from the monolayers were extracted using $2 \mathrm{ml}$ hexane:isopropanol (3:2) mixture evaporated to dryness and then the radioactivity was determined (Ranganathan \& Kern 1998).

\section{Measurement of adipocyte lipolysis}

Lipolysis was determined by measuring the amount of glycerol released by the cells into the medium. The cells were treated with or without saquinavir for $18 \mathrm{~h}$ in $1 \mathrm{ml}$ medium and the glycerol content in the medium was measured using the kit from Sigma Chemical Co.

\section{Incorporation of $P^{35}$ S7-methionine into protein}

The cells were incubated with $\left[{ }^{35} \mathrm{~S}\right]$-methionine for $2 \mathrm{~h}$. The monolayers were washed five times with phosphatebuffered saline and dissolved in $1 \mathrm{ml} 0 \cdot 2 \mathrm{M} \mathrm{NaOH}$ in a microfuge tube. These cell extracts were treated with trichloracetic acid to give a final concentration of $15 \%$ for $2 \mathrm{~h}$ on ice. The tubes were centrifuged and the pellets 
A

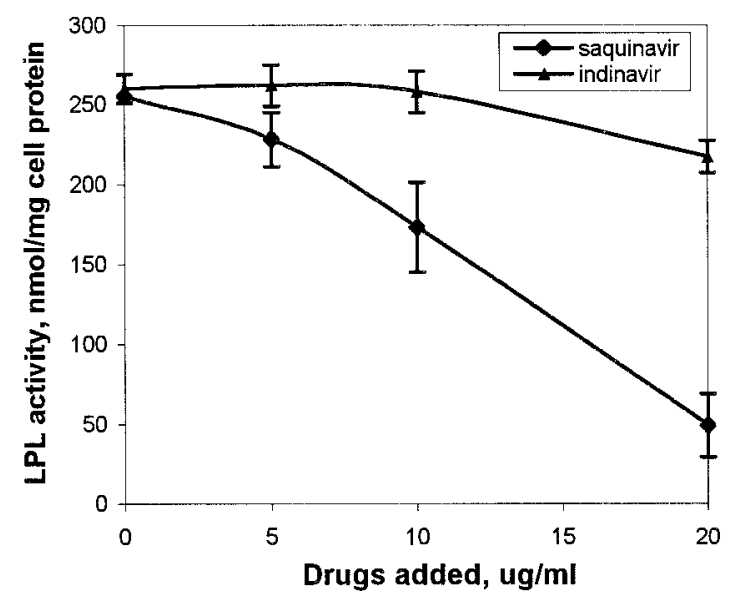

B

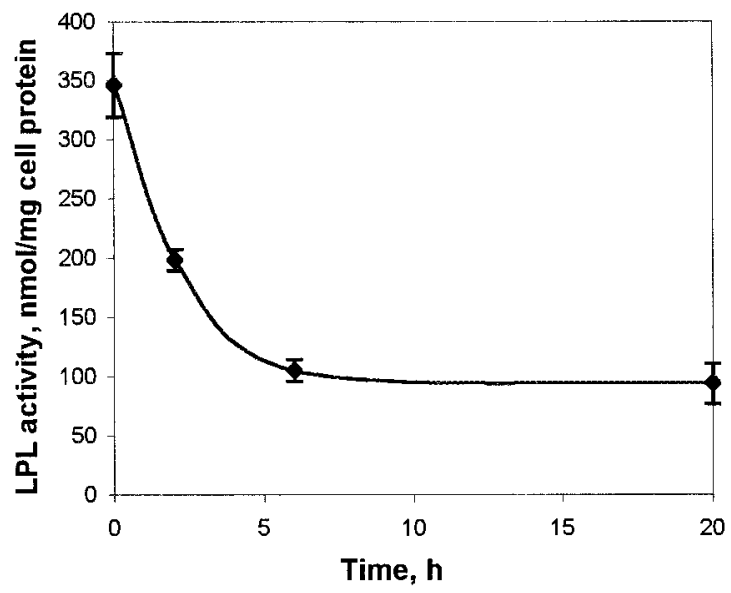

Figure 1 Effect of indinavir and saquinavir on LPL activity in 3T3-F442A adipocytes. (A) Differentiated 3T3-F442A adipocytes were treated with the indicated concentrations of saquinavir and indinavir for $24 \mathrm{~h}$ and the heparin-releasable LPL activity was determined. (B) Differentiated 3T3-F442A adipocytes were treated with saquinavir $(20 \mu \mathrm{g} / \mathrm{ml})$ for the indicated time-periods and the heparin-releasable LPL activity was determined. Each value is the mean of independent analysis from triplicate wells and the error bars represent S.D.

were washed three times with $10 \%$ trichloracetic acid. The pellets were finally dissolved in $0 \cdot 2 \mathrm{M} \mathrm{NaOH}$ and the radioactivity was determined.

\section{RNA extraction and Northern blot analysis}

RNA was isolated from the cells using guanidine thiocyanate as described by Chomczynski \& Sacchi (1987). RNA $(10 \mu \mathrm{g})$ was electrophoresed on a $1 \%$ agaroseformaldehyde gel, transferred to nylon membrane and hybridized with ${ }^{32} \mathrm{P}-$ labeled cDNA probe for mouse LPL.

\section{Western blot analysis}

The cells from each well were lysed in $1.0 \mathrm{ml}$ of a buffer containing Triton X-100 and phenylmethylsulfonylfluoride. The lysates were centrifuged and $10 \mu \mathrm{l}$ of the clear sample was subjected to $10 \%$ SDS-polyacrylamide gel electrophoresis and transferred to a nitrocellulose membrane. LPL was detected using polyclonal antibodies raised against bovine LPL in rabbit and peroxidase-conjugated second antibody. The bands were visualized using chemiluminescence reagents (Amersham Pharmacia Biotech, Piscataway, NJ, USA).

\section{Statistics}

All data are expressed as the mean \pm S.D. of triplicate cell cultures, and all statistical comparisons were made using the Student's $t$-test.

\section{Results}

To examine the effect of protease inhibitors on LPL activity, differentiated 3T3-F442A adipocytes were treated with saquinavir and indinavir for $24 \mathrm{~h}$. The data presented in Fig. 1 show that saquinavir inhibited LPL activity in a dose-dependent manner. The inhibition was $10 \%$ with $5 \mu \mathrm{g} / \mathrm{ml}$ saquinavir $(P=0 \cdot 1)$, and 33 and $81 \%(P<0 \cdot 01)$ with 10 and $20 \mu \mathrm{g} / \mathrm{ml}$ respectively. Plasma concentrations of saquinavir have been reported to be as high as $7 \mu \mathrm{g} / \mathrm{ml}$ during treatment (van Heeswijk et al. 2000). Indinavir caused no inhibition at 5 and $10 \mu \mathrm{g} / \mathrm{ml}$, but inhibited LPL activity by $17 \%$ $(P=0 \cdot 1)$ at $20 \mu \mathrm{g} / \mathrm{ml}$. The time-course of LPL inhibition by saquinavir is also shown in Fig. 1. At a concentration of $20 \mu \mathrm{g} / \mathrm{ml}$, the drug inhibited $43 \% \quad(P<0 \cdot 01)$ of the LPL activity within $2 \mathrm{~h}$ of treatment. At $6 \mathrm{~h}$, the inhibition was $72 \% \quad(P<0 \cdot 01)$ and there was no further decrease in activity at $20 \mathrm{~h}$. Saquinavir did not inhibit LPL activity when added directly to the assay (data not shown).

To determine whether the inhibition of LPL activity could be reversed, differentiated 3T3-L1 adipocytes were treated with $20 \mu \mathrm{g} / \mathrm{ml}$ saquinavir for $18 \mathrm{~h}$ and the cells were washed and incubated further in the absence of the drug. The data presented in Fig. 2 show that the LPL activity was inhibited by $75 \%$ as a result of incubation with saquinavir. After removal of the drug, the LPL activity remained low for $6 \mathrm{~h}$ and after $24 \mathrm{~h} 70 \%$ of the original activity was restored.

Northern blot analysis was carried out to determine if the expression of LPL mRNA was affected by saquinavir. The data shown in Fig. 3 indicate that saquinavir treatment did not inhibit the expression of LPL mRNA even though there was a large decrease in LPL activity. Western blot analysis of the heparin-releasable fraction demonstrated that there was no change in LPL protein although the inhibition of enzyme activity was more than $75 \%$ (Fig. 3). 


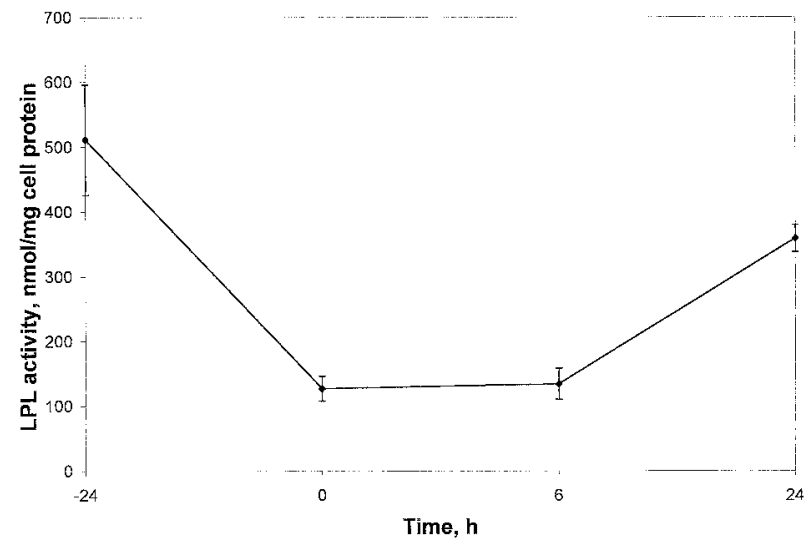

Figure 2 Reversal of the inhibition of LPL activity after removal of saquinavir in 3T3-F442A adipocytes. Differentiated 3T3-F442A adipocytes were treated with saquinavir $(20 \mu \mathrm{g} / \mathrm{ml})$ for $24 \mathrm{~h}$. The cells were washed and incubated with fresh medium without saquinavir for the indicated periods and the heparin-releasable LPL activity was determined. All values are means from triplicate analyses and the error bars represent S.D.

In order to examine whether the protease inhibitors have any effect on lipid biosynthesis, the incorporation of $\left[{ }^{14} \mathrm{C}\right]$-acetate into total lipids was studied. The data presented in Fig. 4A show that saquinavir inhibited lipid synthesis by $74 \%(P<0 \cdot 01)$ after $24 \mathrm{~h}$ treatment at a concentration of $20 \mu \mathrm{g} / \mathrm{ml}$. No significant changes were observed at 5 and $10 \mu \mathrm{g} / \mathrm{ml}$ saquinavir. The time-course of the changes in lipid biosynthesis is shown in Fig. 4B. The inhibition of lipid synthesis was detected as early as $2 \mathrm{~h}$ after the addition of saquinavir, and the inhibition was $53 \%$ and $82 \%$ after $5 \mathrm{~h}$ and $20 \mathrm{~h}$ respectively $(P<0 \cdot 01)$. Indinavir had no effect on lipid biosynthesis under similar conditions (data not shown).

To determine whether the inhibitory effect of saquinavir on LPL and lipid synthesis was due to a general cytotoxic effect, the incorporation of $\left[{ }^{35} \mathrm{~S}\right]$-methionine into total proteins was determined. The results shown in Table 1 indicate that the rate of protein synthesis and the cellular protein concentration remained unchanged after saquinavir treatment. Therefore, saquinavir did not inhibit total protein synthesis in these cells.

The lipodystrophy resulting from the clinical treatment with protease inhibitors could be due to increased lipolysis of triglyceride from fat cells. Therefore, we examined the effects of saquinavir on the release of glycerol from 3T3-F442A adipocytes. The release of glycerol is a measure of triglyceride hydrolysis catalyzed by hormonesensitive lipase. The data in Table 2 show that $20 \mu \mathrm{g} / \mathrm{ml}$ saquinavir increased the basal rate of glycerol release by $82 \%(P<0 \cdot 01)$. No significant changes were observed at lower concentrations of saquinavir.

With the inhibition of LPL activity, lipid synthesis, and increased basal lipolysis, one would expect to observe a decrease in total cell lipid accumulation. To investigate the

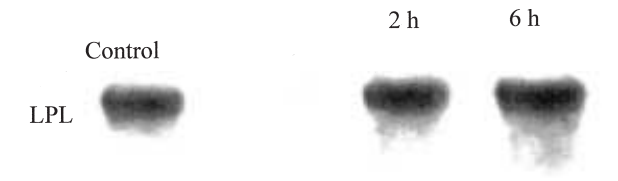

GAPDH

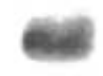

LPL activity

210

120

62
B

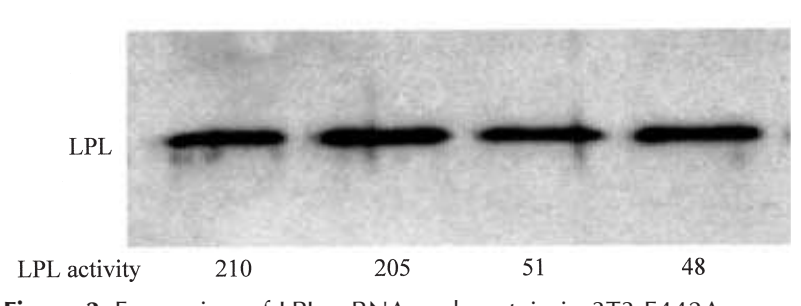

Figure 3 Expression of LPL mRNA and protein in 3T3-F442A adipocytes. (A) Differentiated 3T3-F442A adipocytes were treated with saquinavir $(20 \mu \mathrm{g} / \mathrm{ml})$ for 2 and $6 \mathrm{~h}$. RNA was isolated and subjected to Northern blot analysis. The blots were hybridized with ${ }^{32}$ P-labeled CDNA probes for LPL and glyceraldehyde phosphate dehydrogenase (GAPDH). (B) Differentiated 3T3-F442A adipocytes were treated with saquinavir $(20 \mu \mathrm{g} / \mathrm{ml})$ for $20 \mathrm{~h}$. Western blot analysis was carried out in the heparin-releasable fraction, as described in Materials and Methods. The LPL activities are shown as nmol fatty acids released/mg cell protein.

effect of saquinavir on lipid accumulation, saquinavir was added to 3T3-L1 and 3T3-F442A preadipocytes at the time of differentiation. As shown in Table 3, saquinavir inhibited lipid accumulation in both the cell lines during the differentiation process.

\section{Glucose transport and insulin action}

Protease inhibitor treatment in humans causes disturbances in carbohydrate metabolism. In order to study whether protease inhibitors have any direct effect on glucose transport, 3T3-L1 cells were treated with saquinavir and indinavir and the basal and insulin-stimulated glucose transport was determined. The data shown in Fig. 5A indicate that saquinavir increased the basal glucose transport $2 \cdot 7$-fold $(P<0 \cdot 05)$ and decreased the insulinstimulated glucose transport by $30 \%(P<0 \cdot 05)$. Under the same conditions, indinavir increased basal glucose transport by $40 \%(P<0 \cdot 05)$ and had no effect on the insulin-stimulated glucose transport (Fig. 5B).

\section{Discussion}

The data presented in this paper show that saquinavir has significant effects on LPL activity, de novo lipid synthesis 
A

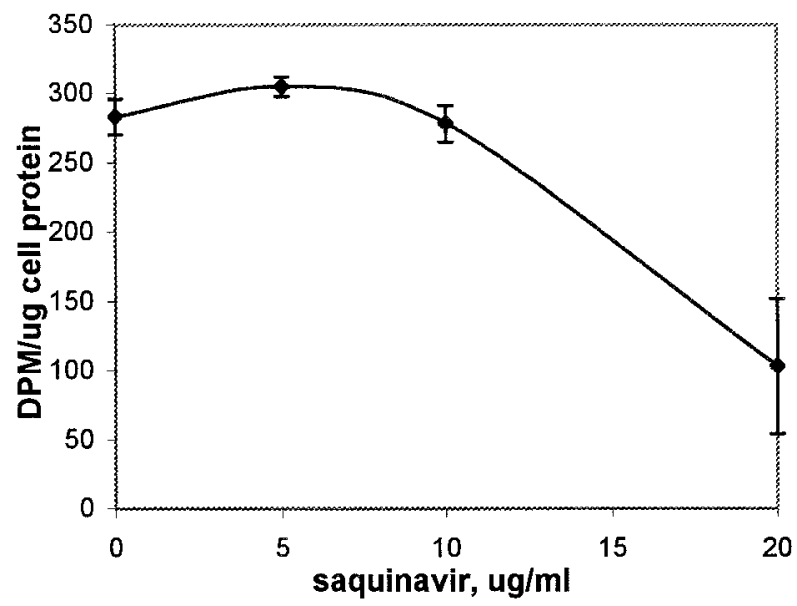

B

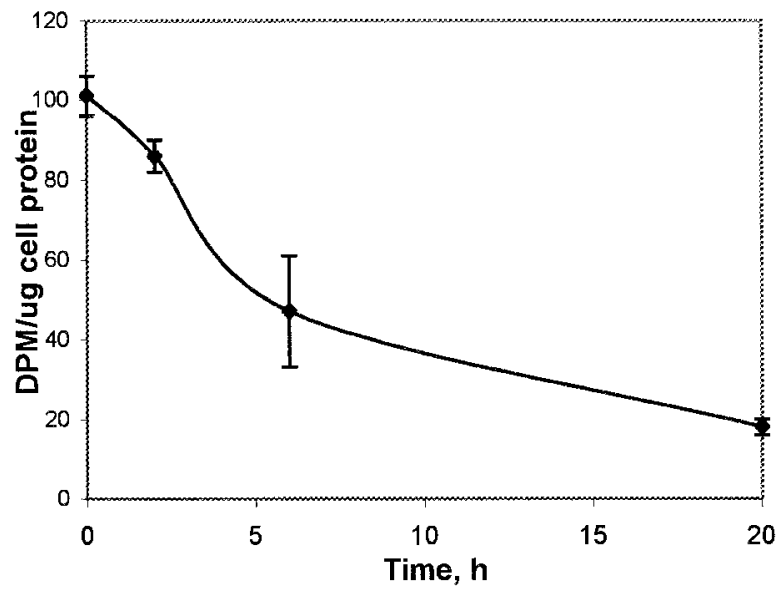

Figure 4 Effect of saquinavir on lipid synthesis from $\left[{ }^{14} \mathrm{C}\right]$-acetate in 3T3-L1 adipocytes. Differentiated 3T3-L1 adipocytes were incubated with the indicated concentrations of saquinavir for $24 \mathrm{~h}$ (A) or $20 \mu \mathrm{g} / \mathrm{ml}$ saquinavir (B) for the indicated periods of time and the incorporation of $\left[{ }^{14} \mathrm{C}\right]$-acetate into total lipids was determined as described in Materials and Methods. The values in the figures represent means and S.D. from triplicate analyses.

Table 1 Effect of saquinavir on protein synthesis and protein content in 3T3-F442A adipocytes. Each value is the average \pm S.D. from triplicate analyses

\section{Saquinavir added}

None

$5 \mu \mathrm{g} / \mathrm{ml}$

$10 \mu \mathrm{g} / \mathrm{ml}$

$20 \mu \mathrm{g} / \mathrm{ml}$ $\left[{ }^{35} \mathrm{~S}\right]-$ Met incorporation $\left(\mathrm{DPM} / \mathrm{mg}\right.$ protein $\left.\times 10^{-3}\right)$

\section{Protein content} $(\mu \mathrm{g})$

$\begin{array}{ll}56 \cdot 5 \pm 19 \cdot 5 & 424 \pm 9 \\ 56 \cdot 3 \pm 13 \cdot 8 & 439 \pm 25 \\ 58 \cdot 8 \pm 24 \cdot 7 & 439 \pm 24 \\ 57 \cdot 9 \pm 11 \cdot 1 & 421 \pm 19\end{array}$

Differentiated 3T3-F442A adipocytes were incubated with $\left[{ }^{35} \mathrm{~S}\right]$-methionine $(10 \mu \mathrm{Ci} / \mathrm{ml})$ for $2 \mathrm{~h}$. The monolayers were washed five times with phosphate-buffered saline and dissolved in $1 \mathrm{ml} 0 \cdot 2 \mathrm{M} \mathrm{NaOH}$ and transferred to a microfuge tube. The radioactivity in the trichloroacetic acid-precipitable materials and the amount of total protein were determined as described in the text.

and lipolysis in adipocytes. Lipid accumulation in adipose tissue requires both LPL-mediated triglyceride hydrolysis and de novo fatty acid synthesis. The inhibitory effects of saquinavir on LPL, fatty acid synthesis and stimulation of lipolysis may be partly responsible for the lipodystrophy in patients treated with this drug.

In patients treated with a combination of saquinavir and nelfinavir, the plasma levels of saquinavir and nelfinavir reached $2.4 \mu \mathrm{g} / \mathrm{ml}$ and $6 \mu \mathrm{g} / \mathrm{ml}$ respectively (Remmel et al. 1999). In another study, plasma concentration of saquinavir has been reported to be as high as $6.8 \mu \mathrm{g} / \mathrm{ml}$ (van Heeswijk et al. 2000). We did not observe any effects of saquinavir at a concentration of $5 \mu \mathrm{g} / \mathrm{ml}$. It is difficult to equate plasma levels of a drug with in vitro data, since tissue levels of these drugs may be higher. Although saquinavir inhibited LPL activity and lipid synthesis, another HIV protease inhibitor, indinavir, had only minimal effects on
Table 2 Effect of saquinavir on glycerol release by 3T3-F442A adipocytes. The values are means \pm S.D. from triplicate wells

\begin{tabular}{ll} 
& $\begin{array}{l}\text { Glycerol release } \\
\text { ( } \mu \text { mol glycerol/ } \\
\text { mg protein })\end{array}$ \\
\cline { 2 - 2 } Saquinavir added & \\
None & $7 \cdot 9 \pm 0 \cdot 1$ \\
$5 \mu \mathrm{g} / \mathrm{ml}$ & $9 \cdot 2 \pm 0 \cdot 1$ \\
$10 \mu \mathrm{g} / \mathrm{ml}$ & $8 \cdot 4 \pm 0 \cdot 5$ \\
$20 \mu \mathrm{g} / \mathrm{ml}$ & $14 \cdot 4 \pm 0 \cdot 1$ \\
\hline
\end{tabular}

Differentiated 3T3-F442A adipocytes were treated with the indicated concentrations of saquinavir for $18 \mathrm{~h}$ in $1 \mathrm{ml}$ medium. The glycerol content in the medium was measured using the kit from Sigma Chemical Co.

adipocytes. The reasons for this difference between saquinavir and indinavir are not clear. The potencies of these drugs to inhibit HIV protease and dosages used for the treatment are very close (Deeks et al. 1997). It is possible that the inhibitory action of saquinavir on lipid metabolism in adipocytes may be unrelated to the inhibition of HIV protease. Although head-to-head comparisons of the effects on lipid and carbohydrate metabolism have not been performed, both these drugs are associated with 'syndrome X'-like presentations. Purnell et al. (2000) found that normal healthy subjects developed hypertriglyceridemia when treated with ritonovir, but no changes in post-heparin plasma lipase activities were observed.

Our data show that LPL translation and the immunoreactive mass of LPL are unaffected by saquinavir treatment in spite of strong inhibition of enzyme activity. Therefore, saquinavir appears to inhibit post-translational processing, resulting in the synthesis of LPL protein with low activity. This mechanism appears to be similar 
Table 3 Inhibition of lipid accumulation in 3T3-L1 and 3T3-F442A adipocytes by saquinavir. The values are means \pm S.D. from triplicate determinations

\begin{tabular}{|c|c|c|}
\hline & $\begin{array}{l}\text { 3T3-F442A } \\
\text { ( } \mu \text { g triglyceride/ } \\
\text { mg protein) }\end{array}$ & $\begin{array}{l}\text { 3T3-L1 } \\
\text { ( } \mu \text { g triglyceride/ } \\
\text { mg protein) }\end{array}$ \\
\hline ontrol & $57 \cdot 5 \pm 5 \cdot 0$ & $38 \cdot 7 \pm 2 \cdot 1$ \\
\hline $\begin{array}{l}\text { Saquinavir } \\
\qquad(20 \mu \mathrm{g} / \mathrm{ml})\end{array}$ & $20 \cdot 5 \pm 3 \cdot 0$ & $25 \cdot 8 \pm 4 \cdot 5$ \\
\hline
\end{tabular}

3T3-F442A and 3T3-L1 cells were cultured until they were confluent and saquinavir was added at the beginning of the differentiation period. In the case of 3T3-L1 cells, saquinavir was added after the 2-day treatment with IBMX/dexamethasone/insulin mixture. The culture was continued for 4 days and the lipid accumulation was measured by total cellular triglyceride content using the triglyceride assay kit.

to the inhibition of LPL activity by thiazolidinediones (Ranganathan \& Kern 1998) and regulation of LPL by feeding and fasting (Doolittle et al. 1990).

These data may yield some insight into the lipodystrophy associated with treatment of patients with HIV protease inhibitors. Adipose tissue lipid content represents the result of a constant flux of new lipid accrual and ongoing lipolysis. As demonstrated previously (Hollenberg 1966), the increase in lipid content of rat adipose tissue was due to the accrual of predominantly unsaturated (plasma-derived) fatty acids, as opposed to saturated lipid from endogenous synthesis. Human adipose tissue also derives most of its lipid for storage from circulating triglycerides (Shrago et al. 1969, Wilson et al. 1973). Thus, adipose tissue lipid accumulation is dependent on the uptake of lipids from triglyceride-rich lipoproteins, and probably to a small extent from endogenous de novo fatty acid synthesis. On the other hand, patients with LPL deficiency are not deficient in adipose tissue triglyceride (Peeva et al. 1992), suggesting that adipocytes will synthesize lipid de novo if the need arises.

Adipose tissue lipid accumulation is also determined by the degree of lipolysis. Hormone-sensitive lipase (HSL) is the primary mediator of lipolysis in adipocytes (Osuga et al. 2000). Hormones that stimulate cAMP activate protein kinase A, which then reversibly phosphorylates HSL (Stralfors et al. 1984, Holm et al. 1997) and releases non-esterified fatty acids from adipocytes. The increased release of non-esterified fatty acids plays a central role in insulin resistance (Kelley \& Simoneau 1994, Unger 1995). In addition, an elevated expression of HSL in adipocytes led to reduced adipose lipid accumulation, along with the delayed expression of late markers of adipocyte differentiation (Sztalryd et al. 1995). Thus, the control of adipose tissue lipid accumulation may result in alterations in expression of other adipose tissue genes. These changes in adipocyte gene expression could be due to an inhibition of differentiation. Previous studies have reported that protease inhibitors inhibited the differentiation of preadipocytes in culture as measured by glycerophosphate dehydrogenase, lipid accumulation and LPL expression
A

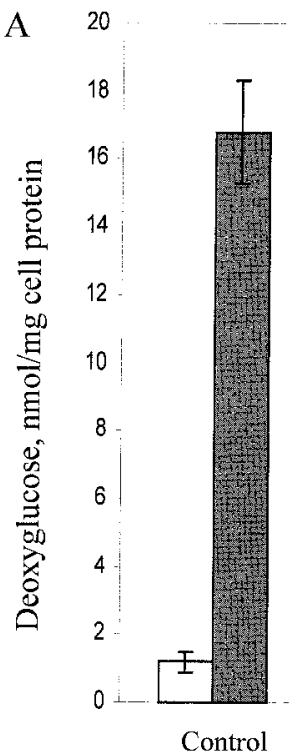

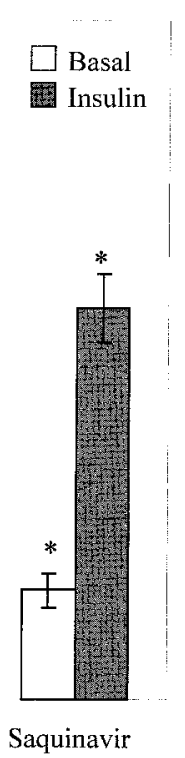

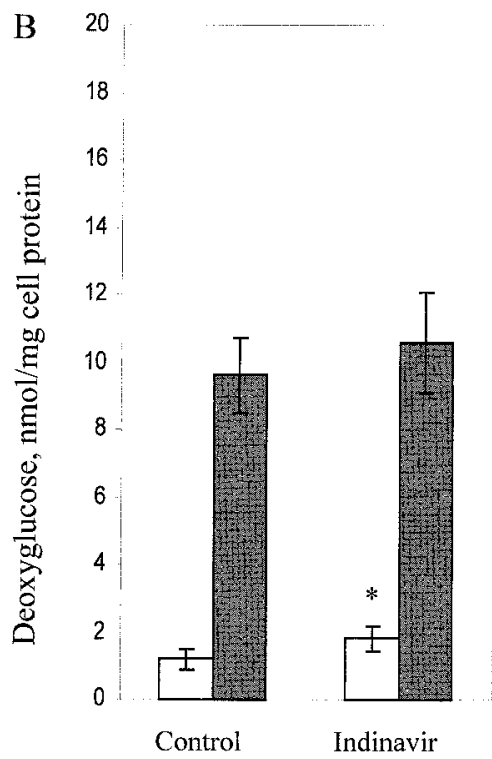

Figure 5 Effect of (A) saquinavir and (B) indinavir on basal and insulin-stimulated glucose transport in 3T3-L1 adipocytes. Differentiated 3T3-L1 adipocytes were treated with $20 \mu \mathrm{g} / \mathrm{ml}$ saquinavir or indinavir for $24 \mathrm{~h}$ and the basal and insulin-stimulated $\left[{ }^{3} \mathrm{H}\right]-2$ deoxyglucose was determined as described in Materials and Methods. The results are expressed as the mean of triplicate analyses and the error bars represent S.D. ${ }^{*} P<0.05$ compared with the corresponding control values. 
(Wentworth et al. 1999, Zhang et al. 1999, Lenhard et al. 2000a). Our studies show that saquinavir has potent effects on LPL activity and lipolysis in mature adipocytes also. Lenhard et al. (2000a) have also reported that some of the protease inhibitors including saquinavir increase lipolysis in cultured C3H10T1/2 adipocytes. Caron et al. (2001) have recently reported that indinavir impairs preadipocyte differentiation in 3T3-F442A cells.

Although decreased lipogenesis and increased lipolysis would be predicted to cause adipose wasting, patients treated with these drugs demonstrate a redistribution of adipose tissue lipids, suggesting that these drugs have depot-specific actions. There are numerous metabolic differences between different adipose tissue depots in humans. For example, gluteofemoral adipocytes have higher LPL activity, whereas the adipocytes in the central fat depot have higher lipolytic activity and rapid turnover of fatty acids (Despres et al. 1995, Samaras \& Campbell 1999). Recently, Lenhard et al. (2000b) have shown that the protease inhibitors nelfinavir and ritonovir stimulated triglyceride synthesis in HepG2 cells and increased plasma triglyceride in mice (Lenhard et al. 2000b). The variable effects of the protease inhibitors in different tissues may be cause for the lipodystrophy in specific regions in the body.

The treatment of patients with protease inhibitors also causes insulin resistance and hyperglycemia in some individuals. The studies presented in this paper have shown direct effects of saquinavir on glucose transport and insulin action in cultured adipocytes. The data indicate that saquinavir decreased the insulin-stimulated glucose transport in 3T3-L1 adipocytes, although there was an increase in basal glucose transport. Although decreased adipocyte glucose transport is often highly correlated with decreased whole body glucose disposal rate (Kolterman et al. 1981), most whole body glucose disposal occurs in muscle (DeFronzo et al. 1981). It is not known whether changes in adipose tissue insulin action subsequently affect muscle glucose transport, or whether saquinavir has direct effects on muscle. In addition, it is not clear why indinavir did not have any effect on glucose transport or insulin action in these in vitro studies, since the clinical syndrome associated with indinavir is similar to that of saquinavir. Caron et al. (2001) have reported that treatment of 3T3-F442A preadipocytes with indinavir for 6 days during the differentiation period inhibited the insulin-stimulated mitogenactivated protein kinase activation. However, insulin receptor substrate-1 phosphorylation was not affected.

The cellular actions of the HIV protease inhibitors that would account for the effects in adipose tissue are not known. Tumor necrosis factor- $\alpha$ (TNF $\alpha$ ) is secreted by the adipocytes and it is known to inhibit LPL and increase lipolysis. The inhibition of LPL activity by TNF $\alpha$ is transcriptionally mediated (Cornelius et al. 1988). Since we observed no changes in LPL mRNA, the inhibition of LPL by saquinavir is not likely to be mediated through stimulation of TNFa secretion.
In summary, these data show that the treatment of adipocytes with one of the HIV protease inhibitors resulted in a decrease in LPL activity and lipogenesis, increase in lipolysis, and a decrease in insulin-stimulated glucose transport. These data may explain some of the adverse effects observed in the patients treated with protease inhibitors, but raise many questions regarding depot specificity, and the mechanism of cellular signaling in adipocytes.

\section{Acknowledgements}

This work was supported by a Merit Review Grant from the Veterans Administration, and DK 39176 from the National Institute of Health.

\section{References}

Belfrage P \& Vaughn M 1969 Simple liquid-liquid partition system for isolation of labeled oleic acid from mixture with glycerides. Journal of Lipid Research 10 341-344.

Caron M, Auclair M, Vigouroux C, Glorian M, Forest C \& Capeau J 2001 The HIV protease inhibitor indinavir impairs sterol regulatory element-binding protein-1 intranuclear localization, inhibits preadipocyte differentiation, and induces insulin resistance. Diabetes 50 1378-1388.

Carr A, Samaras K, Chisholm DJ \& Cooper DA 1998 Pathogenesis of HIV-1-protease inhibitor-associated peripheral lipodystrophy, hyperlipidaemia, and insulin resistance. Lancet 351 1881-1883.

Carr A, Samaras K, Thorisdottir A, Kaufmann GR, Chisholm DJ \& Cooper DA 1999 Diagnosis, prediction, and natural course of HIV-1 protease-inhibitor-associated lipodystrophy, hyperlipidaemia, and diabetes mellitus: a cohort study. Lancet 353 2093-2099.

Chomczynski P \& Sacchi N 1987 Single-step method of RNA isolation by acid guanidinium thiocyanate-phenol-chloroform extraction. Analytical Biochemistry 162 156-159.

Clancy BM \& Czech MP 1990 Hexose transport stimulation and membrane redistribution of glucose transporter isoforms in response to cholera toxin, dibutyryl cyclic AMP and insulin in 3T3-L1 adipocytes. Journal of Biological Chemistry 265 12434-12443.

Cornelius P, Enerback S, Bjursell G, Olivecrona T \& Pekala PH 1988 Regulation of lipoprotein lipase mRNA content in 3T3-L1 cells by tumour necrosis factor. Biochemical Journal 249 765-769.

Deeks SG, Smith M, Holodniy M \& Kahn JO 1997 HIV-1 protease inhibitors. Journal of the American Medical Association 277 145-153.

DeFronzo RA, Jacot E, Jequier E, Maeder E, Wahren J \& Felber JP 1981 The effect of insulin on the disposal of intravenous glucose. Results from indirect calorimetry and hepatic and femoral venous catheterization. Diabetes 30 1000-1007.

Despres J-P, Lemieux S, Lamarche B, Prud'homme D, Moorjani S, Brun L-D, Gagne C \& Lupien P-J 1995 The insulin resistancedyslipidemic syndrome: contribution of viceral obesity and therapeutic implications. International Journal of Obesity 19 S76-S86.

Doolittle MH, Ben-Zeev O, Elovson J, Martin D \& Kirchgessner TG 1990 The response of lipoprotein lipase to feeding and fasting. Evidence for posttranslational regulation. Journal of Biological Chemistry 265 4570-4577.

Echevarria KL \& Hardin TCSJA 1999 Hyperlipidemia associated with protease inhibitor therapy. Annals of Pharmacotherapy 33 859-863.

van Heeswijk RP, Veldkamp AI, Mulder JW, Meenhorst PL, Lange JM, Beijnen JH \& Hoetelmans RM 2000 Once-daily dosing of 
saquinavir and low-dose ritonavir in HIV-1-infected individuals: a pharmacokinetic pilot study. AIDS 14 F103-F110.

Hollenberg CH 1966 The origin and glyceride distribution of fatty acids in rat adipose tissue. Journal of Clinical Investigation $\mathbf{4 5}$ 205-216.

Holm C, Langin D, Manganiello V, Belfrage P \& Degerman E 1997 Regulation of hormone-sensitive lipase activity in adipose tissue. Methods in Enzymology 286 45-67.

Kelley DE \& Simoneau JA 1994 Impaired free fatty acid utilization by skeletal muscle in non-insulin-dependent diabetes mellitus. Journal of Clinical Investigation 94 2349-2356.

Kohl NE, Emini EA, Schleif WA, Davis LJ, Heimbach JC, Dixon RA, Scolnick EM \& Sigal IS 1988 Active human immunodeficiency virus protease is required for viral infectivity. PNAS 85 4686-4690.

Kolterman OG, Gray RS, Griffin J, Burstein J, Insel J, Scarlett JA \& Olefsky JM 1981 Receptor and postreceptor defects contribute to the insulin resistance in non-insulin-dependent diabetes mellitus. Journal of Clinical Investigation 68 957-969.

Lenhard JM, Furfine ES, Jain RG, Ittoop O, Orband-Miller LA, Blanchard SG, Paulik MA \& Weiel JE 2000a HIV protease inhibitors block adipogenesis and increase lipolysis in vitro. Antiviral Research 47 121-129.

Lenhard JM, Croom DK, Weiel JE \& Winegar DA $2000 b$ HIV protease inhibitors stimulate hepatic triglyceride synthesis. Arteriosclerosis, Thrombosis and Vascular Biology 20 2625-2629.

Navia MA, Fitzgerald PMD, McKeever BM, Leu C-T, Heimbach JC, Herber WK, Sigal IS, Darke PL \& Springer JP 1988 Three-dimensional structure of aspartyl protease from human immunodeficiency virus HIV-1. Nature 337 615-620.

Nilsson-Ehle P \& Schotz MC 1976 A stable radioactive substrate emulsion for assay of lipoprotein lipase. Journal of Lipid Research $\mathbf{1 7}$ $536-541$.

Osuga J, Ishibashi S, Oka T, Yagyu H, Tozawa R, Fujimoto A, Shionoiri F, Yahagi N, Kraemer FB, Tsutsumi O et al. 2000 Targeted disruption of hormone-sensitive lipase results in male sterility and adipocyte hypertrophy, but not in obesity. PNAS $\mathbf{9 7}$ 787-792.

Peeva E, Brun LD, Ven Murthy MR, Després J-P, Normand T, Gagné C, Lupien P-J \& Julien P 1992 Adipose cell size and distribution in familial lipoprotein lipase deficiency. International Journal of Obesity 16 737-744.

Periard D, Telenti A, Sudre P, Cheseaux J-J, Halfon P, Reymond MJ, Marcovina SM, Glauser MP, Nicod P, Darioli R et al. 1999 Atherogenic dyslipidemia in HIV infected individuals treated with protease inhibitors. Circulation 100 700-705.
Purnell JQ, Zambon A, Knopp RH, Pizzuti DJ, Achari R, Leonard JM, Locke C \& Brunzell JD 2000 Effect of ritonavir on lipids and post-heparin lipase activities in normal subjects. AIDS 14 51-57.

Ranganathan S \& Kern PA 1998 Thiazolidinediones inhibit lipoprotein lipase activity in adipocytes. Journal of Biological Chemistry 273 26117-26122.

Remmel RP, Kawle SP, Weller D \& Fletcher CV 1999 Simultaneous HPLC assay for quantification of indinavir, nelfnavir, ritonavir, and saquinavir in human plasma. Clinical Chemistry 46 73-81.

Samaras K \& Campbell LV 1999 The non-genetic determinants of central adiposity. International Journal of Obesity 21 839-845.

Schapiro JM, Winters MA, Stewart F, Efron B, Norris J, Kozal MJ \& Merigan TC 1996 The effect of high-dose saquinavir on viral load and CD4+T-cell counts in HIV-infected patients. Annals of Internal Medicine 124 1039-1050.

Shrago E, Spennetta T \& Gordon E 1969 Fatty acid synthesis in human adipose tissue. Journal of Biological Chemistry 244 2761-2766.

Stralfors P, Bjorgell P \& Belfrage P 1984 Hormonal regulation of hormone sensitive lipase in intact adipocytes: identification of phosphorylated sites and effects on the phosphorylation by lipolytic hormones and insulin. PNAS 81 3317-3321.

Sztalryd C, Komaromy MC \& Kraemer FB 1995 Overexpression of hormone-sensitive lipase prevents triglyceride accumulation in adipocytes. Journal of Clinical Investigation 95 2652-2661.

Unger RH 1995 Lipotoxicity in the pathogenesis of obesity-dependent NIDDM. Genetic and clinical implications. Diabetes 44 863-870.

Visnegarwala F, Krause KL \& Musher DM 1997 Severe diabetes associated with protease inhibitor therapy. Annals of Internal Medicine 127947.

Wentworth JM, Burris TP \& Chatterjee VKK 1999 HIV protease inhibitors block human preadipocyte differentiation, but not via the PPARy/RXR heterodimer. Journal of Endocrinology 164 R7-R10.

Wilson JP, Gutman R \& Galton DJ 1973 Comparison of free fatty acid and glyceride fatty acid uptake by human adipose tissue. Metabolism 22 913-921.

Zhang B, Macnaul K, Szalkowski D, Li Z, Berger J \& Moller DE 1999 Inhibition of adipocyte differentiation by HIV protease inhibitors. Journal of Clinical Endocrinology and Metabolism $\mathbf{8 4}$ 4274-4277.

Received in final form 31 August 2001

Accepted 24 September 2001 